\title{
In vitro assessment of the antihyperglycemic and antioxidant properties of araçá, butiá and pitanga
}

\author{
Juliana Vinholes*, Graciele Lemos, Rosa Lia Barbieri, Rodrigo C. Franzon, Márcia Vizzotto* \\ Embrapa Clima Temperado, BR 392, KM 78, C. P. 403, CEP 96010-971 Pelotas, RS, Brazil
}

\section{A R T I C L E I N F O}

\section{Keywords:}

Brazilian native fruits

$\alpha$-Glucosidase inhibition, Antioxidant activity

Phenolic compounds

Carotenoids

Sugars

\begin{abstract}
A B S T R A C T
Native fruits have been known as a great source of bioactive compounds with potential biological effects. The aim of this study was to investigate the $\alpha$-glucosidase inhibition and antioxidant activities of araçá (Psidium cattleianum Sabine), butiá (Butia odorata (Barb. Rodr.) Noblick) and pitanga (Eugenia uniflora L.) and relate their chemical composition with the observed biological activity. Samples of mature fruits were extracted with ethanol and the observed biological activities were dependent of the species and concentration as well. Araçás were the strongest $\alpha$-glucosidase inhibitors ( $\mathrm{IC}_{50}$ value of $25.4 \pm 0.7$ and $31.8 \pm 0.7 \mu \mathrm{g} / \mathrm{ml}$, respectively). Pitangas showed antiradical activities against DPPH, hydroxyl and nitric oxide radicals. Orange pitanga and butiá from Santa Vitória do Palmar were the most active concerning anion superoxide radical. All fruits are rich in total phenolic compounds with values in the range of $454.5 \pm 17.3-908.3 \pm 60.8 \mathrm{mg}$ of equivalents of chlorogenic acid/100 g fresh weight. Purple pitanga stood out due to their levels of anthocyanins and carotenoids. Fruits showed similar amounts of total sugars, araçás and pitangas showed higher levels of reducing sugars while butiás were the richest ones in non-reducing sugars. Fruits with lower $\mathrm{IC}_{50}$ values for $\alpha$-glucosidase inhibition were correlated with higher concentrations of reducing sugars, phenolic compounds, anthocyanins and carotenoids and grouped by principal component analysis (PCA). The obtained results indicate that these native fruits are promising sources of $\alpha$-glucosidase inhibitors and antioxidants that can be used to control glycemia in patients with type 2 Diabetes mellitus.
\end{abstract}

\section{Introduction}

Fruits are important source of phytochemicals on our diet and its consumption is associated with the lower risk of developing Diabetes mellitus (Muraki et al., 2013). In addition, different studies shows that specific fruits, including exotic fruits, can be used for treatment of various health problems including obesity and diabetes (Balisteiro, Alezandro, \& Genovese, 2013; Devalaraja, Jain, \& Yadav, 2011). Type 2 Diabetes mellitus (T2DM) is a metabolic disorder, characterized by chronic hyperglycemia that leads to alterations on the metabolism of carbohydrates, fats and proteins resulting from defects in insulin secretion or action, or both. Control of T2DM can be made through rigorous diets, physical activity, and the use of drugs acting for instance on insulin production or inhibition of enzymes associated with degradation of carbohydrates such as $\alpha$-glucosidase. Different Brazilian native fruits have been exploited as potential source of biological active compounds (Bagetti et al., 2011; Beskow et al., 2014; Denardin \& Parisi, 2014; Denardin, Hirsch et al., 2014; Medina et al., 2011) and some of these research are focusing their application as $\alpha$-glucosidase inhibitors to control diabetes (Gonçalves, Lajolo, \& Genovese, 2010). $\alpha$-Glucosidase inhibitors (e.g. acarbose, miglitol, and voglibose) are agents used by diabetic patients, responsible to reversible inhibit the $\alpha$-glucosidase enzyme in order to retard the absorption of dietary carbohydrates and suppress postprandial hyperglycemia (Li, Qian, \& Li, 2010). Nevertheless, due to huge diversity of native fruits in Brazil there are different species that remains to be studied. From these fruits, we can highlight three native species with increase commercial interest namely Psidium cattleyanum Sabine (Myrtaceae), Butia odorata (Barb. Rodr.) Noblick (Arecaceae) and Eugenia uniflora L. (Myrtaceae) (Hoffmann, Barbieri, Rombaldi, \& Chaves, 2014; Mitra, Irenaeus, Gurung, \& Pathak, 2012).

$P$. cattleyanum fruits, known as strawberry guava and particularly in Brazil as araçá, araçá-amarelo, araçá-vermelho or araçá-do-campo, are ovoid or oblong, weighting less than $20 \mathrm{~g}$, and can have yellow or red peel with white pulp. Fruits are rich in vitamin C and phenolic compounds, being epicatechin and gallic acid their main constituents (Medina et al., 2011). Its fruits are known to possess antioxidant activity (Medina et al., 2011; Nora et al., 2014; Lozano, Vélez \& Rojano, 2013), analgesic effect (Alvarenga et al., 2013), antimicrobial (Medina

\footnotetext{
* Corresponding authors.

E-mail addresses: julianarochavinholes@gmail.com (J. Vinholes), marcia.vizzotto@embrapa.br (M. Vizzotto).
} 
et al., 2011), antiproliferative effect (Medina et al., 2011), anti-glycated activity (Yan, Lee, Kong, \& Zhang, 2013).

B. odorata, known as butiá, produces ovoid to depressed-globose fruits, ranging from yellow to orange to red in colour, with a sweet, acidic taste and whose pulp is source of fibres, pro vitamin A, vitamin C, potassium and carotenoids (Beskow et al., 2014). B. odorata is poorly exploited about their biological potential, however, antioxidant (Beskow et al., 2014) and probiotic activities (Cruxen et al., 2017) have been reported to them.

E. uniflora, also known as pitanga, Brazilian cherry or Surinam cherry is a globoid fruit, with $3 \mathrm{~cm}$ in diameter, and presents eight to ten longitudinal grooves, looking like a small pumpkin (Celli, PereiraNetto, \& Beta, 2011). The fruits colour depends on the variety, but ranges from orange to purple, and the fruit has an exotic flavour, sweet and sour taste (Lima, Mélo, \& Lima, 2002). The fruits are a source of anthocyanins, flavonoids and carotenoids and antioxidant activity (Bagetti et al., 2011; Denardin, Hirsch et al., 2014; Pereira et al., 2012; Vissotto, Rodrigues, Chisté, Benassi, \& Mercadante, 2013), antiproliferative (Denardin \& Parisi, 2014) and anti-inflammatory (Soares et al., 2014) activities have been reported.

Considering the suggestion that native fruits are a good source of biological active compounds and some species shows potential as inhibitors of carbohydrates-hydrolyzing enzymes, the present work aims to determine the chemical composition and evaluated the $\alpha$-glucosidase inhibitory properties and antioxidant activities of three Brazilian native fruits extracts, namely araçá ( $P$. cattleyanum), butiá (B. odorata) and pitanga (E. uniflora), in order to use this natural resource in the treatment of type 2 Diabetes mellitus.

\section{Materials and methods}

\subsection{Standards and reagents}

Reagents were purchased from different suppliers. 2,2-Diphenyl-1picrylhydrazyl radical (DPPH), ethylenediaminetetraacetic acid disodium salt (EDTA-Na), iron sulphate heptahydrate, salicylic acid, $\beta$ nicotinamide adenine dinucleotide reduced form (NADH), phenazine methosulphate (PMS), nitroblue tetrazolium chloride (NBT), 5,5'-dithiobis(2-nitrobenzoic acid) (DTNB), sulphanilamide, n-(1-Naphthyl) ethylenediamine dihydrochloride, sodium nitroprussiate (SNP), phosphate buffer ( $\mathrm{pH} 7.0$ ), $\alpha$-glucosidase (type I from baker's yeast), 4-nitrophenyl $\alpha$-D-glucopyranoside (PNP-G), $\alpha$-amylase (from porcine pancreas), beta-carotene, cyanidin-3-O-glucoside, Folin-Ciocalteu reagent, chlorogenic acid, sodium bicarbonate anhydrous and sodium carbonate were obtained from Sigma-Aldrich (St. Louis, MO, USA). Glycose, copper sulphate, sodium sulphate anhydrous and ethanol were purchased from Synth (Diadema, SP, Brazil), ethyl ether, dichloromethane, ascorbic acid, phosphoric acid, hydrogen peroxide solution (30\% w/w) were from Impex (Diadema, SP, Brazil). Ammonium molibdate, sodium arsenate dibasic and potassium sodium tartrate were from VETEC (Duque de Caxias, RJ, Brazil) and sulfuric acid was from MERCK (Darmstadt, Germany).

\subsection{Samples}

Yellow and red selections of araçá ( $P$. cattleyanum) and orange, red and purple-fleshed selections of pitanga fruits (E. uniflora) were obtained from the Active Germplasm Bank of native fruits at Embrapa Clima Temperado. Samples of butiá (B. odorata) were collected in three different locations, one sample from Herval ( $\left.32^{\circ} 1^{\prime} 24^{\prime \prime} \mathrm{S}, 53^{\circ} 23^{\prime} 44^{\prime \prime} \mathrm{W}\right)$, one from Santa Vitória do Palmar ( $\left.33^{\circ} 31^{\prime \prime} 8^{\prime \prime} \mathrm{S}, 53^{\circ} 22^{\prime \prime} 5^{\prime \prime} \mathrm{W}\right)$ and another one from Pelotas (Active Germplasm Bank of native fruits at Embrapa Clima Temperado, $31^{\circ} 40^{\prime} 47^{\prime \prime} \mathrm{S}, 52^{\circ} 26^{\prime} 24^{\prime \prime} \mathrm{W}$ ). The fruits were sampled searching for a mixture of completely ripe fruits. All fruits were harvested in 2015, between March and April. Fruits were selected considering the absence of visible injury and infections, and also colour and size uniformity, and were frozen $\left(-20^{\circ} \mathrm{C}\right)$ until analysis.

\subsection{Preparation of extracts}

Fruit extract was prepared from the edible portions of fruits: i) skins and pulps of butiá and pitanga; and ii) skin, pulp and seeds of araçá. At least 10 fruits were combined for each sample that were thawed at room temperature and sliced. Samples $(5 \mathrm{~g})$ were extracted using $98 \%$ ethanol $(1: 4, \mathrm{w} / \mathrm{v})$ during $5 \mathrm{~min}$ using an Ultra-Turrax homogenizer (Ika, Artur Nogueira, São Paulo, Brazil). The homogenates were filtered through paper filter (Whatman no 4) and further evaporated under pressure at $40{ }^{\circ} \mathrm{C}$. Samples were reconstituted in $20 \mathrm{ml}$ of ethanol/water $(3: 1, v / v)$ and stored at $-20^{\circ} \mathrm{C}$ until analysis. Extractions were performed in triplicate and yields are shown in Table 1.

\subsection{Chemical composition}

\subsubsection{Total phenolic compounds}

Total phenolic content was measured according to the Folin-Ciocalteu method adapted from Swain and Hillis (1959). Briefly $50 \mu \mathrm{l}$ aliquot of the extract and the control ( $50 \mu \mathrm{l}$ of ethanol) were each combined with $250 \mu \mathrm{l}$ of $0.25 \mathrm{~N}$ Folin-Ciocalteu reagent. After $3 \mathrm{~min}$ reaction, $500 \mu \mathrm{l}$ of $\mathrm{Na}_{2} \mathrm{CO}_{3}(1 \mathrm{~N})$ was added, the mixtures were incubated for $2 \mathrm{~h}$ at room temperature, and the absorbance was measured at $725 \mathrm{~nm}$. The results were expressed as chlorogenic acid equivalents (CAE g/100 g fresh weight) using a chlorogenic acid $(0-0.5 \mathrm{mg} / \mathrm{ml})$ standard curve.

\subsubsection{Total anthocyanins}

Anthocyanins content was achieved using the method adapted from Fuleki and Francis (1968). Briefly, $425 \mu$ l of extract was mixed with $75 \mu \mathrm{l}$ of $\mathrm{HCl} 1.5 \mathrm{M}$ and measured at $535 \mathrm{~nm}$. The anthocyanins concentration was expressed as equivalent of cyanidin-3-glucoside (C3G g/100 g fresh weight), using cyanidin-3-glucoside standard curve $(0-0.4 \mathrm{mg} / \mathrm{ml})$

\subsubsection{Total carotenoids}

Carotenoid content was adapted from Talcott and Howard (1999). An aliquot of acetone $(0.6 \mathrm{ml})$ was added to $0.6 \mathrm{ml}$ of extract, hexane $(1.5 \mathrm{ml})$ was further added and vigorous mixed. Samples were allowed to rest during $30 \mathrm{~min}$ and the organic layer was read at $470 \mathrm{~nm}$. Carotenoids concentration was expressed as equivalent of $\beta$-carotene ( $\beta$ - $\mathrm{CE}$ $\mathrm{g} / 100 \mathrm{~g}$ fresh weight), using $\beta$-carotene standard curve $(0-0.4 \mathrm{mg} / \mathrm{ml})$.

\subsubsection{Total, reducing and non-reducing sugar contents}

Total, reducing and non-reducing sugar contents were determined with the adapted method described by Nelson (1944). Briefly, sample $(100 \mu \mathrm{l})$ was diluted in distillated water $(1 \mathrm{ml})$ and neutralized to $\mathrm{pH} 7$ (glacial acetic acid). An aliquot $(500 \mu \mathrm{l})$ of neutralized extract was mixed with $\mathrm{Ba}(\mathrm{OH})_{2}(0.2 \mu \mathrm{l}), \mathrm{ZnSO}_{4}(0.2 \mu \mathrm{l})$ and distillated water $(4.0 \mathrm{ml})$, vortexed and allowed to stand $(10 \mathrm{~min})$ to precipitate proteins. Samples were filtered with paper filter (Whatman 1) and $1.0 \mathrm{ml}$ was mixed with distillated water $(1.0 \mathrm{ml})$ plus cupric reagent $(1.0 \mathrm{ml})$ and heated $\left(100{ }^{\circ} \mathrm{C}, 20 \mathrm{~min}\right)$. Samples were cool down in ice water bath and arsenomolibdic reagent $(1.0 \mathrm{ml})$ was added plus $5.0 \mathrm{ml}$ of distillated water. Reducing sugars was estimated spectrophotometrically at $510 \mathrm{~nm}$, using a standard curve constructed from a glucose solution $(0-180.0 \mathrm{mg} / \mathrm{ml})$. For total sugar content samples were first heated $\left(100{ }^{\circ} \mathrm{C}, 15 \mathrm{~min}\right)$ with concentrated $\mathrm{HCl}(1.0 \mathrm{ml}$ of sample to $25 \mu \mathrm{L}$ of $\mathrm{HCl}$ ), neutralized with $\mathrm{Na}_{2} \mathrm{CO}_{3}$ and followed the protein removing step and analysis of reducing sugars. Non-reducing sugars were calculated by difference of total sugars minus reducing sugars. Analysis were carried out in triplicate and expressed as $\mathrm{mg} / 100 \mathrm{~g}$ of sample. 


\subsection{Anti-hyperglycaemic and antioxidant potential}

2.5.1. General

For the evaluation of the anti-hyperglycaemic and antioxidant potential of fruit extracts in vitro assays were performed applying spectrophotometric methods using a Amersham, Model UV Vis Ultrospec3100 Pro Amersham Bioscience spectrophotometer. The $\mathrm{IC}_{50}$ values were calculated using at least 5 concentrations for each extract. Percentage of inhibition (I \%) for each assay was calculated using the following formulae:

$\left.I \%=\left[\left(A_{\text {control }}-A_{\text {sample }}\right)\right) / A_{\text {control }}\right] \times 100$

where $A_{\text {control }}$ is the absorbance of the control reaction (containing all reagents except the extract), and $A_{\text {sample }}$ is the absorbance of the tested extract in the reaction mixture.

\subsection{2. $\alpha$-Glucosidase inhibitory activity}

The effect on $\alpha$-glucosidase was assessed using a procedure previously reported (Vinholes et al., 2011) with a slightly modification. Briefly, $20 \mu \mathrm{l}$ of fruit extract or ethanol (control) was added to a vial with $100 \mu \mathrm{l}$ of PNP-G (3.25 mM) in phosphate buffer ( $\mathrm{pH} 7.0)$. The reaction was initiated by the addition of $100 \mu \mathrm{l}$ of enzyme $(9.37 \mathrm{U} / \mathrm{ml}$ in phosphate buffer, $\mathrm{pH} \mathrm{7.0)}$ and vials were incubated at $37^{\circ} \mathrm{C}$ for $10 \mathrm{~min}$. The reaction was stopped by adding $0.600 \mathrm{ml}$ of $\mathrm{Na}_{2} \mathrm{CO}_{3}(1 \mathrm{M})$ and the absorbance at $405 \mathrm{~nm}$ was measured.

\subsection{3. $D P P H$ scavenging activity}

The hydrogen atoms or electrons donation ability of the extracts was measured from the bleaching of purple coloured methanol solution of $\mathrm{DPPH}^{*}$ by adaptation of the methods reported in the literature (Vinholes et al., 2011; Vinholes, Gonçalves, Martel, Coimbra, \& Rocha, 2014). Briefly, $100 \mu \mathrm{l}$ of each extract or ethanol (control) were added to $1000 \mu \mathrm{l}$ of a $0.6 \mathrm{mM} \mathrm{DPPH}^{*}$ methanol solution. The reaction was mixed and incubated in the dark for $30 \mathrm{~min}$ at room temperature, samples were read at $515 \mathrm{~nm}$

\subsubsection{Superoxide radical scavenging activity}

Superoxide radicals were generated by the NADH/PMS (nicotinamide adenine dinucleotide reduced form/phenazine methosulphate) system (Vinholes et al., 2011). The reaction mixture contained $100 \mu \mathrm{l}$ of different concentrations of extracts or ethanol (control) and NADH (100 $\mu \mathrm{l}$ of $1.89 \mathrm{mM}$ ), nitrotetrazolium blue (NBT, $100 \mu \mathrm{l}$ of $48.92 \mu \mathrm{M}$ ) and the reaction started by the addition of $100 \mu \mathrm{l}$ of PMS $(47.70 \mu \mathrm{M})$. Samples were incubated during $5 \mathrm{~min}$ at room temperature and read at $560 \mathrm{~nm}$ as described by Zou, Lu, and Wei (2004).

\subsubsection{Hydroxyl radical inhibition}

Hydroxyl radical scavenging activity was measured according to Vinholes et al. (2014). To initiate the reaction, $0.75 \mathrm{ml}(3 \mathrm{mM})$ salicylic acid was added to the individuals reaction mixtures containing $0.25 \mathrm{ml}$ of each extract or ethanol (control), plus $1.1 \mathrm{ml}$ of iron sulphate heptahydrate solution ( $8 \mathrm{mM}$, prepared in EDTA-Na $20 \mu \mathrm{M}$ ) and $0.5 \mathrm{ml}$ of $\mathrm{H}_{2} \mathrm{O}_{2}$ solution (7 mM). After vortexing, the reaction was incubated at $37{ }^{\circ} \mathrm{C}$ for $30 \mathrm{~min}$ and then the absorbance $(515 \mathrm{~nm})$ of $1 \mathrm{ml}$ supernatant was determined.

\subsubsection{Nitric oxide radical scavenging activity}

The nitric oxide radical scavenging activity was determined spectrophotometrically according to a described procedure (Vinholes et al., 2011). Briefly, after incubation of sodium nitroprusside (SNP, $20 \mathrm{mM}$, $100 \mu \mathrm{l})$ with extracts $(100 \mu \mathrm{l})$ or ethanol (control, $100 \mu \mathrm{l})$ for $60 \mathrm{~min}$ at room temperature, under light, Griess reagent $(100 \mu \mathrm{l})$ was added. The mixture was then incubated at room temperature in the dark for $10 \mathrm{~min}$ and the absorbance of the chromophore formed was read at $562 \mathrm{~nm}$.

\subsection{Statistical analysis}

All experiments results were performed in triplicate $(n=9)$ and expressed as \pm standard error of the mean (SEM). Pearson correlation coefficients ( $r$ ) was applied in order to evaluate the strength of the correlation between the variables under study: Total phenolic compounds, Total anthocyanins, Total carotenoids, Total sugar, Reducing sugar and non-reducing sugar contents and the activity $\left(\mathrm{IC}_{50}\right)$ of the native fruit ethanolic extracts, expressed in $\mathrm{mg}$ of extract/100 $\mathrm{g}$ of fruit (Table S.1). Principal Component Analysis (PCA) was carried out to transform the original variables into a new set of linearly uncorrelated factors, principal components (PCs) that could be ranked based upon their contribution for explaining the variation of the whole data set. Additionally, PCA can also establish relations between samples and variables (Xu, Hagler, Xu, \& Hagler, 2002). The first and second PCs corresponded to the largest possible variance of the original variables. The results were represented in a biplot (score plot and loading plot), which showed the distribution of the samples and the correlation of the five original variables to the two PCs. PCA was calculated using the Analyset-it ${ }^{\circledR}$ application for Microsoft Excel program.

\section{Results and discussion}

\subsection{Phytochemicals}

Phenolic compounds have been described with a range of therapeutic effects on different diseases such as cancer, cardiovascular diseases, atherosclerosis and diabetes. It is well stablished by different studies that the total phenolic composition of a matrix gives an idea of how rich this product is in antioxidants, since these parameters are closely related. Fruit samples were extracted using ethanol $95 \%$ at $4: 1$ proportion $(\mathrm{v} / \mathrm{w})$ which was considered the most suitable solvent system in order to achieve high concentration of phenolic compounds and $\alpha$-glucosidase inhibition (data not shown). Levels of phenolic compounds in native fruits varied from $454.5 \pm 17.3$ to $908.3 \pm 60.8 \mathrm{mg}$ of equivalents of chlorogenic acid/100 $\mathrm{g}$ fresh weight (Table 1). The total phenolic compound was similar between the two araçá genotypes. Phenolic compounds in butiás varied from $454.5 \pm 17.3$ to $540.9 \pm 63.0 \mathrm{mg}$ of equivalents of chlorogenic acid/ $100 \mathrm{~g}$ fresh weight. Butiá collected in Pelotas was the poorest one, while those from Santa Vitória do Palmar and Herval showed similar values (Table 1). Amounts of phenolic compounds in pitangas varied from $517.2 \pm 37.3-908.3 \pm 60.8 \mathrm{mg}$ of equivalents of chlorogenic acid $100 \mathrm{~g}$ fresh weight among the genotypes. Purple pitanga was the richest one, followed by red and orange genotypes (Table 1). The total phenolic compounds obtained for all samples are consistent with those results reported in the literature (Bagetti et al., 2011; Beskow et al., 2014; Denardin, Hirsch et al., 2014; Fetter, Vizzotto, Corbelini, \& Gonzalez, 2010; Medina et al., 2011). All these fruits can be considered great sources of phenolic compounds when compared with other more common and widely consumed fruits such as red apple and pear $(125 \mathrm{mg} / 100 \mathrm{~g})$, black grape $(213 \mathrm{mg} / 100 \mathrm{~g})$ and strawberry (199 mg/100 g) (Giada, 2013). Additionally, purple pitanga showed total phenolic values higher than black raspberry, lemon and grapefruit (670, 843 and $893 \mathrm{mg} / 100 \mathrm{~g}$, respectively), which are in the top of the list of fruits rich in phenolic compounds (Giada, 2013).

Amounts of anthocyanins in the native fruits varied from $0.6 \pm 0.1$ to $450.4 \pm 36.5 \mathrm{mg}$ of equivalents of cyanidin-3-glucoside/ $100 \mathrm{~g}$ fresh weight (Table 1). The concentration of anthocyanins in red araçá was almost 21 times higher than in yellow araçá genotype. Yellow araçá concentrations were 2-6 times higher than that reported in the literature for three araçás accessions, but 5 times lower than one of them (Medina et al., 2011). In the case of red araçá anthocyanins were 4-6 times higher in the present study (Medina et al., 2011). Butiás showed similar anthocyanin concentrations, ranging from $1.2 \pm 0.4$ to $1.5 \pm 0.1 \mathrm{mg}$ of equivalents of cyanidin-3-glucoside/100 $\mathrm{g}$ fresh 
Table 1


(Pelotas, Santa Vitória do Palmar (SVP) and Herval) and pitanga (purple, red and orange genotypes).

\begin{tabular}{|c|c|c|c|c|c|c|c|}
\hline \multirow[t]{2}{*}{ Samples } & \multirow[b]{2}{*}{$\begin{array}{c}\text { Yield } \\
(\%)\end{array}$} & \multicolumn{3}{|c|}{ Phytochemicals } & \multicolumn{3}{|c|}{ Sugars $^{\mathrm{d}}$} \\
\hline & & Total Phenolic compounds ${ }^{\mathrm{a}}$ & Anthocyanins ${ }^{\mathrm{b}}$ & Carotenoids ${ }^{\mathrm{c}}$ & Total & Reducing & Non-Reducing \\
\hline \multicolumn{8}{|l|}{ Araçá } \\
\hline Yellow & $8.55 \pm 0.42$ & $603.1 \pm 18.9$ & $1.3 \pm 0.4$ & $442.7 \pm 46.1$ & $8.2 \pm 1.7$ & $7.9 \pm 0.1$ & $1.3 \pm 0.1$ \\
\hline Red & $9.47 \pm 0.23$ & $606.1 \pm 15.3$ & $29.3 \pm 1.4$ & $364.4 \pm 24.9$ & $7.7 \pm 1.3$ & $5.6 \pm 0.1$ & $1.4 \pm 0.2$ \\
\hline \multicolumn{8}{|l|}{ Butiá } \\
\hline Pelotas & $12.95 \pm 0.59$ & $454.5 \pm 17.3$ & $1.5 \pm 0.1$ & $2865.2 \pm 190.4$ & $10.4 \pm 0.9$ & $3.1 \pm 0.3$ & $7.3 \pm 0.6$ \\
\hline SVP & $12.67 \pm 0.53$ & $535.9 \pm 56.2$ & $1.9 \pm 0.1$ & $1710.3 \pm 243.2$ & $14.7 \pm 2.1$ & $2.2 \pm 0.1$ & $12.6 \pm 2.0$ \\
\hline Herval & $8.22 \pm 0.46$ & $540.9 \pm 63.0$ & $1.2 \pm 0.4$ & $2155.5 \pm 580.5$ & $8.9 \pm 0.8$ & $2.1 \pm 0.1$ & $6.7 \pm 0.7$ \\
\hline \multicolumn{8}{|l|}{ Pitanga } \\
\hline Purple & $12.12 \pm 0.27$ & $908.3 \pm 60.8$ & $450.4 \pm 36.5$ & $10,116.7 \pm 889.6$ & $9.6 \pm 0.2$ & $9.4 \pm 0.1$ & $0.2 \pm 0.5$ \\
\hline Red & $8.97 \pm 0.19$ & $517.2 \pm 37.3$ & $60.1 \pm 5.3$ & $5697.6 \pm 820.6$ & $7.5 \pm 0.2$ & $7.1 \pm 0.1$ & $0.4 \pm 0.1$ \\
\hline Orange & $12.30 \pm 0.13$ & $526.6 \pm 40.2$ & $0.6 \pm 0.1$ & $9061.3 \pm 514.9$ & $10.8 \pm 0.6$ & $8.9 \pm 0.7$ & $1.8 \pm 0.1$ \\
\hline
\end{tabular}

Results are expressed as mean \pm SD of three experiments done in triplicate $(n=9)$.

${ }^{\mathrm{a}} \mathrm{mg}$ of equivalents of chlorogenic acid/100 $\mathrm{g}$ fresh weight.

${ }^{b} \mathrm{mg}$ of equivalents of cyanidin-3-glucoside/100 $\mathrm{g}$ fresh weight.

c $\mu \mathrm{g}$ of equivalents of $\beta$-carotene $/ 100 \mathrm{~g}$ fresh weight.

${ }^{\mathrm{d}} \mathrm{g} / 100 \mathrm{~g}$ fresh weight.

weight, values similar than that reported in the literature (Beskow et al., 2014). Higher concentrations of these compounds were found in pitanga samples (Table 1), with the exception of the orange genotype. Purple pitanga showed a concentration of anthocyanins almost 7 times higher than the red genotype. All pitanga fruits evaluated showed higher concentrations of anthocyanins than other studies (Bagetti et al., 2011). Anthocyanins are water soluble pigments commonly found in coloured flowers and fruits where they are responsible for the insects, birds and animals attraction to achieve pollination and seed dispersion. Besides, these compounds are also related with beneficial effects over diseases such as diabetes and obesity, cardiovascular diseases and cancer (Vinholes, Gelain, \& Vizzotto, 2016).

Carotenoids are also colourful pigments abundant in fruits and vegetables. The amounts of total carotenoids in native fruits varied from $364.4 \pm 24.9$ to $10,116.7 \pm 889.6 \mu \mathrm{g}$ of equivalents of $\beta$-carotene/ $100 \mathrm{~g}$ of fresh weight (Table 1). Araçás were the poorest native fruits concerning carotenoids, the value found for the yellow genotype is in agreement with the literature, but higher values were reported for the red genotype (Medina et al., 2011). Butiás showed levels of carotenoids from $1710.3 \pm 243.2$ to $2865.2 \pm 190.4 \mu \mathrm{g}$ of equivalents of $\beta$-carotene $/ 100 \mathrm{~g}$ of fresh weight, values similar to those found by other authors (Beskow et al., 2014). Higher levels of carotenoids were found in pitangas which varied from $5697.6 \pm 820.9$ to $10,116.7 \pm 889.6 \mu \mathrm{g}$ of equivalents of $\beta$-carotene/g fresh weight. Purple sample was the richest one, followed by orange and red genotypes, which is consistent with other authors (Denardin, Hirsch et al., 2014).

According with the classification proposed by Britton and Khachik (2009) araçás can be classified as moderate carotenoids providers $(100-500 \mu \mathrm{g} / 100 \mathrm{~g})$; butiá from Santa Vitória do Palmar is classified as high (500-2000 $\mu \mathrm{g} / 100 \mathrm{~g})$; and butiás from Pelotas and Herval and all pitangas (purple, red and orange) are considered very high carotenoids providers ( $>2000 \mu \mathrm{g} / 100 \mathrm{~g}$ ). Besides their pigments properties carotenoids are considered important bioactive compounds for human's health as scientific studies demonstrate their important role in reducing the risk of degenerative diseases (Rao \& Rao, 2007).

\subsection{Sugars content}

Total sugar content in native fruits varied between $7.5 \pm 0.2 \%$ and $14.7 \pm 2.1 \%$, reducing sugar between $2.1 \pm 0.1 \%$ and $9.4 \pm 0.1 \%$ and non-reducing sugars between $0.4 \pm 0.1 \%$ and $12.6 \%$ (Table 1 ). Yellow araçá genotype showed higher values of total and reducing sugars than the red genotype, and both genotypes showed lower values than previously reported (Nora et al., 2014). Butiá from Santa Vitória do Palmar showed the highest content on total and non-reducing sugars, followed by butiás from Pelotas and Herval. The total amounts of sugars in these samples are in agreement with results reported in the literature (Ferrão et al., 2013). Orange pitanga was the richest one in total sugar, followed by purple and red genotypes and these values are similar to those found by other authors (Bagetti et al., 2011). Overall, the total sugar content in native fruits was lower than common fruits such as apple (25 g/100 g), bananas (19 g/100 g) and grapes (20 g/100 g).

\section{3. $\alpha$-Glucosidase inhibition}

Diabetes mellitus is a chronic disease and a major public health, with high social and health care costs since it affects over 387 million people worldwide causing 4.9 million deaths in 2014, according to the International Diabetes Federation. In Brazil, there are around 13 million people between 20 and 79 years old diagnosed with T2DM, representing $6.3 \%$ of the population (SBD, 2013). Under the assay conditions all native fruits ethanolic extracts, with the exception of butiá from Pelotas, showed a dose dependent inhibitory response over $\alpha$ glucosidase (Fig. 1). Native fruits extracts showed IC $_{50}$ values varying from $25.4 \pm 0.7$ to $3264.9 \pm 87.1 \mu \mathrm{g} / \mathrm{ml}$ (Table 2). Araçás genotypes were the most active extracts with $\mathrm{IC}_{50} 13$ and 16 times lower than the acarbose (positive control). Butiás extracts were the less effective ones, only the sample from Herval showed results comparable to the acarbose. Purple pitanga was the most effective among pitanga samples, followed by red and orange genotypes with $\mathrm{IC}_{50} 6,5$ and 2 times lower than the acarbose (Table 2). From these native fruits, as far as we know, only pitanga has been reported with $\alpha$-glucosidase inhibition properties (Correia, Borges, Medeiros, \& Genovese, 2012). Nevertheless, the reported IC $_{50}(1150 \mu \mathrm{g} / \mathrm{ml})$ is $5-17$ times higher than those found in the present study (Table 2). Comparatively to other native fruits from the Myrtaceae family, the same of araça and pitanga, lower $\mathrm{IC}_{50}$ was obtained in the present study. Campomanesia phaea Berg. (cambuci), Psidium guineensis Sw. (araçá), Eugenia stipitata Mc. Vaugh (araçá-boi) and Myrciaria dubia Mc. Vaugh (camu-camu) methanolic extracts were reported with $\mathrm{IC}_{50}$ of $300,600,1000$ and $1300 \mu \mathrm{g} / \mathrm{ml}$. This difference on activity obtained by these authors can be due the extraction solvent used, in both studies methanol was used instead of ethanol. Both solvents are good solvent extractors of phenolic compounds but ethanol is reported to extract more phenolic compounds with consequent higher biological potential (Do et al., 2014). Besides, ethanol is safe for human consumption. 

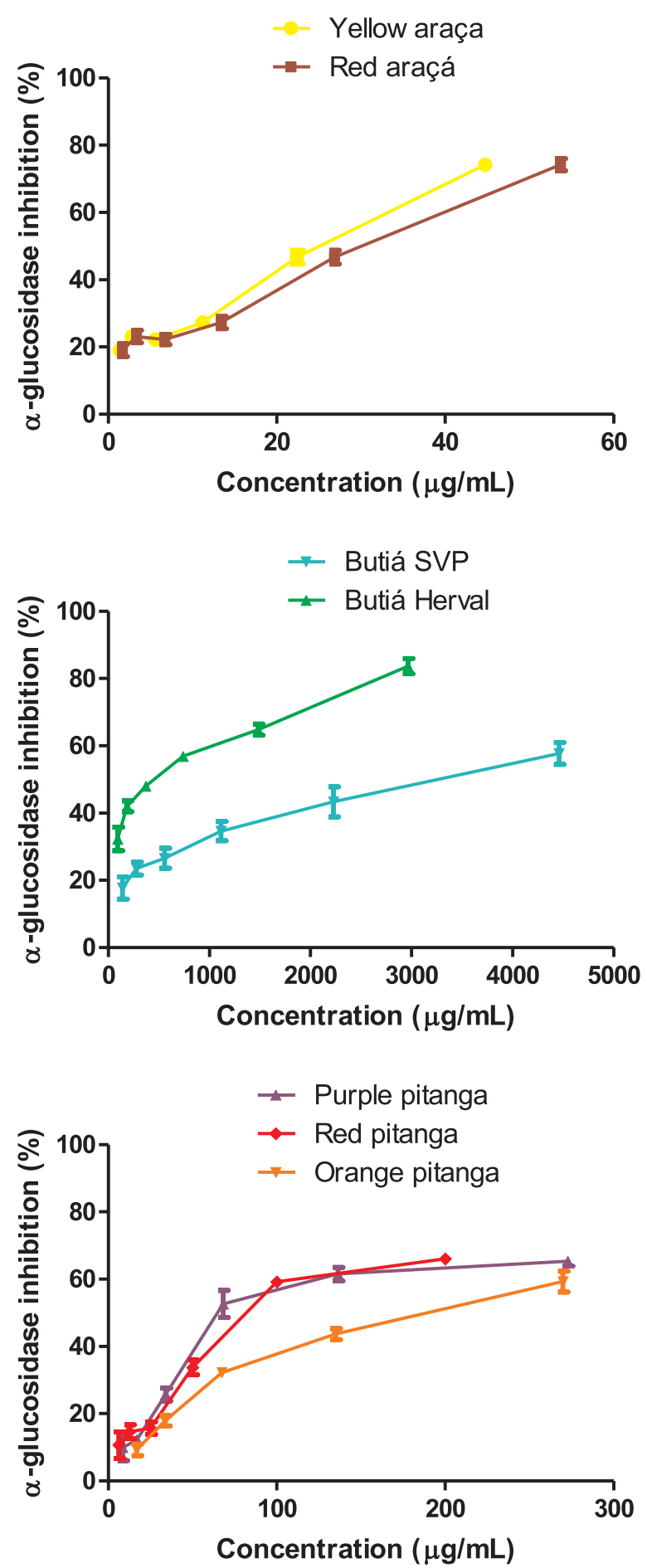

Fig. 1. Inhibition of $\alpha$-glucosidase activity by araçás (yellow and red), butiás (Pelotas, Santa Vitória do Palmar (SVP) and Herval), and pitangas (purple, red and orange) ethanolic extracts. Values show means \pm standard error of the mean (SEM) from three experiments performed in triplicate. (For interpretation of the references to color in this figure legend, the reader is referred to the web version of this article).

\subsection{Antioxidant activity}

As recent studies shows that T2DM patients have an increased freeradical production and reduced antioxidant defences can leads to different health complications, supplementation with antioxidants agents can be useful in their treatment. Thus, the antiradical potential of native fruits extracts was evaluated.

The $\mathrm{DPPH}^{*}$ assay was used for a first screening of extracts ability to scavenge free radicals. All native fruit extracts were able to scavenge $\mathrm{DPPH}^{\circ}$ in a concentration-dependent way (Fig. 2A) with $\mathrm{IC}_{50}$ varying from 160.4 to $610 \mu \mathrm{g} / \mathrm{ml}$ (Table 2). Butiá from Herval was the most effective extract against DPPH, however, all extracts showed lower inhibition when compared with the positive control quercetin (Table 2).

Differently from $\mathrm{DPPH}$, superoxide radical $\left(\mathrm{O}_{2}{ }^{-}\right)$is a physiological radical capable of generate other reactive species, like hydroxyl radical and peroxynitrite. The extracts exhibited $\mathrm{O}_{2}{ }^{--}$scavenging activity and the observed effect was dependent on the concentration for all extracts, exceptionally for butiá from Pelotas (Fig. 2B). Variation on IC $_{50}$ values were from 83.5 to $518.9 \mu \mathrm{g} / \mathrm{ml}$, orange pitanga was the most efficient extract (Table 2). Nevertheless, all extracts showed $\mathrm{IC}_{50}$ values higher than quercetin. Apart from araçás that were reported with lower $\mathrm{IC}_{50}$ (Ribeiro et al., 2014), this is the first report about the $\mathrm{O}_{2}{ }^{-}$scavenging activity of butiás and pitangas samples, as far as we are concerned.

Hydroxyl radicals are physiologically free radicals that are able to induce strand breakage contributing to biological damage, being therefore closely related with the origin of different human diseases. In the present study, native fruit extracts were able to inhibit hydroxyl radicals in a dose-dependent way (Fig. $2 \mathrm{C}$ ). The calculated IC $_{50}$ varied from 114.7 to $1350.1 \mu \mathrm{g} / \mathrm{ml}$ (Table 2). Inhibition against hydroxyl radicals can be classified as follow: orange pitanga $>$ red pitanga $>$ purple pitanga $>$ red araçá $>$ yellow araçá $>$ butiá from Herval $>$ butiá from Pelotas $>$ butiá from Santa Vitória do Palmar (Table 2). Quercetin was tested as positive control, in the concentration range of $1.5-95.0 \mu \mathrm{g} / \mathrm{ml}$, however, under our experimental conditions it did not showed hydroxyl scavenge capacity.

Nitric oxide radical ( $\mathrm{NO}$ ) is involved in different physiological functions, for example it control blood pressure, platelet function, vasodilatation, acts as neurotransmitters and is also implicated in antimicrobial defense. Nevertheless, when its presence exceeds the organism antioxidant capacity, different biological damages can occur, especially when it reacts with superoxide radical forming peroxynitrite a major oxidant produced in vivo. Peroxynitrite in the presence of certain reactive centers may form three of the most reactive and damage species in biological systems: hydroxyl radicals; nitrogen dioxide free radical and nitronium cation (Malinski, 2000). In the present study, native fruit extracts were able to mild scavenging activities over $\mathrm{NO}$, although with was dependent of the concentration (Fig. 2D), with $\mathrm{IC}_{25}$ of $780-3800 \mu \mathrm{g} / \mathrm{ml}$. These values were much higher than the positive control (quercetin).

\subsection{Correlation and PCA analysis}

The Pearson's correlation coefficients for the chemical composition and observed activities for the native fruit ethanolic extracts are shown in Fig. 3. $\alpha$-Glucosidase inhibition was positively correlated with total and non-reducing sugars, indicating that samples with high concentrations of both were less effective against the enzyme. The same behavior was observed for anion superoxide radical that correlates positively with total phenolic compounds and total anthocyanins and hydroxyl and nitric oxide radicals with positive correlation with nonreducing sugars. Negative correlations were observed between hydroxyl and nitric oxide radicals and the amounts of non-reducing sugars, indicating that samples with low concentrations of these compounds were more effective antioxidants. PCA was used to evaluate the main sources of variability of the native fruit extracts in order to understand if there is a relation between the variables (chemical composition and their biological activity) and between samples (araçás, butiás and pitangas). Fig. 3 displays the PCA biplot representing the variables using calibrated axes where the observations (points) are projected on to the axes giving an approximation of the real value. The two first dimensions explain $74.2 \%$ of the variability being PC1 responsible for $52.0 \%$ of the variance and PC2 for $22.2 \%$. According to Fig. 3 native fruits were distinguished into three groups: araçás (AY and AR) and pitangas (PR and $\mathrm{PO}$ ); purple pitanga (PP); and butiás (BP, BH and BSVP). Araçás 
Table 2

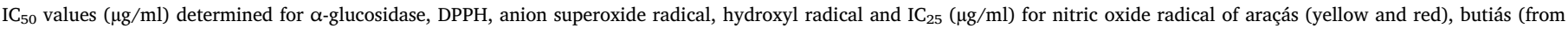
Pelotas, Santa Vitória do Palmar (SVP) and Herval), and pitangas (purple, red and orange) ethanolic extracts and positive controls.

\begin{tabular}{|c|c|c|c|c|c|}
\hline \multirow[t]{2}{*}{ Samples } & $\alpha$-glucosidase & DPPH & Anion superoxide radical & Hydroxyl radical & Nitric oxide radical \\
\hline & \multicolumn{4}{|l|}{$\mathrm{IC}_{50}(\mu \mathrm{g} / \mathrm{ml})$} & $\mathrm{IC}_{25}(\mu \mathrm{g} / \mathrm{ml})$ \\
\hline \multicolumn{6}{|l|}{ Araçá } \\
\hline Yellow & $25.4 \pm 0.7$ & $334.3 \pm 16.5$ & $173.3 \pm 34.6$ & $358.2 \pm 50.7$ & $1360.0 \pm 190.0$ \\
\hline Red & $31.8 \pm 0.7$ & $490.3 \pm 35.1$ & $218.9 \pm 7.4$ & $245.9 \pm 34.5$ & $1650.0 \pm 220.0$ \\
\hline \multicolumn{6}{|l|}{ Butiá } \\
\hline Pelotas & - & $610.9 \pm 4.5$ & - & $1280.9 \pm 135.8$ & $3800.0 \pm 40.0$ \\
\hline SVP & $3264.9 \pm 87.1$ & $257.2 \pm 16.2$ & $96.0 \pm 0.6$ & $1350.1 \pm 53.0$ & $2770.0 \pm 100.0$ \\
\hline Herval & $451.5 \pm 14.1$ & $160.4 \pm 1.1$ & $228.9 \pm 12.6$ & $1142.7 \pm 142.9$ & $1790.0 \pm 190.0$ \\
\hline \multicolumn{6}{|l|}{ Pitanga } \\
\hline Purple & $66.3 \pm 2.4$ & $229.9 \pm 22.1$ & $518.9 \pm 33.6$ & $213.7 \pm 31.8$ & $780.0 \pm 5.0$ \\
\hline Red & $83.2 \pm 2.3$ & $212.1 \pm 22.4$ & $195.4 \pm 3.6$ & $184.7 \pm 7.4$ & $1060.0 \pm 150.0$ \\
\hline Orange & $212.2 \pm 7.1$ & $317.6 \pm 9.6$ & $83.5 \pm 7.8$ & $114.7 \pm 8.8$ & $1250.0 \pm 150.0$ \\
\hline \multicolumn{6}{|c|}{ Positive controls } \\
\hline Acarbose & $413.6 \pm 20.2$ & - & - & - & - \\
\hline Quercetin & $10.5 \pm 1.3$ & $2.3 \pm 0.1$ & $8.9 \pm 0.6-$ & - & $44.6 \pm 3.0$ \\
\hline
\end{tabular}

(AY and AR) and pitangas (PR and PO) were distinguished from the other mainly by their contents in reducing sugars. The distinction of pitanga from purple genotype was due the high concentrations of total phenolic, total anthocyanins and total carotenoids compounds. Butiás (BP, BH and BSVP) were grouped by their high amounts of total sugars and non-reducing sugars. The chemical groups responsible for the $\alpha$ glucosidase inhibition and antioxidant activities are located into the negative PC1 (Fig. 3). It can be observed that samples with high concentrations of reducing sugars are closely related with low $\mathrm{IC}_{50}$ values for $\alpha$-glucosidase and hydroxyl radicals. In addition, the amounts of total phenolic compounds, total anthocyanins and total carotenoids are related with the activities against the enzyme and the radicals, especially nitric oxide, however in a less extend.

As observed by both Pearson's correlation and PCA analysis, Table 3 and Fig. 3, the extracts activities can be partially explained by their composition. Samples with low $\mathrm{IC}_{50}$ for $\alpha$-glucosidase inhibition were grouped and the observed activity related with their amounts of reducing sugars, phenolic compounds, anthocyanins and carotenoids (Fig. 3). Actually, different biological activities have been attributed to phenolic compounds, including the $\alpha$-glucosidase and antioxidant activities studied here in. Although it had been suggest by different studies a positive correlation between the total amounts of phenolic compounds and anthocyanins and the biological activity, this was not observed in the present study (Table 3). These results indicate that the type and amounts of individual phenolic compounds present in these matrices seems to drive the inhibitory effect. Nevertheless, the amounts of phenolic compounds and anthocyanins provided by the extracts can be partially responsible for the $\alpha$-glucosidase inhibition and can also offer good antioxidant protection for patients with T2DM (Matsui et al., 2001). Other important phytochemicals are carotenoids that are colourful pigments abundant in fruits and vegetables. Carotenoids are considered important bioactive compounds for human's health as scientific studies demonstrate their important role in reducing the risk of degenerative diseases (Rao \& Rao, 2007). These compounds are present in high concentrations in purple pitanga genotype and in less extend in red and orange genotypes (Table 1), all samples showed low $\mathrm{IC}_{50}$ values for $\alpha$-glucosidase inhibition and hydroxyl radicals (Table 2). Different studies have demonstrated significant decrease of plasma antioxidants by carotenoids ( $\alpha$ - and $\gamma$-tocopherol, $\alpha$ and $\beta$-carotene, lycopene, $\beta$-cryptoxanthin, lutein and zeaxanthin) in the progression of diabetes and its associated complications such as endothelial dysfunction and atherosclerosis (Polidori et al., 2000; Polidori, Stahl, Eichler, Niestroj, \& Sies, 2001; Valabhji et al., 2001). As far as we are concerned carotenoids have never been studied as inhibitors of $\alpha$-glucosidase, however, as previously stated, they are important phytochemicals that could prevent the development of degenerative diseases. This fact is mainly because carotenoids are important antioxidant compounds, they have been reported as active towards anion superoxide and hydroxyl radicals, two deleterious radicals species that can be in the origin of different degenerative diseases which were inhibited by the native fruits extracts in the present study (Trevithick-Sutton, Foote, Collins, \& Trevithick, 2006). Concerning reducing sugars and their role on $\alpha$-glucosidase inhibition there is no evidences on the literature correlating the amounts of this group of compounds and the $\alpha$-glucosidase inhibition. However, it was recently reported that $\alpha$-glucose, $\beta$-glucose and fructose are correlated with the $\alpha$-glucosidase inhibition of Neptunia oleracea Lour. (Lee et al., 2016) and fructose was correlated with the enzyme inhibitory activity observed for Ipomoea aquatica Forssk. (Sajak, Abas, Ismail, \& Khatib, 2016). These results indicate that the enzyme inhibition and antioxidant activity might be probably due to interaction between the different compounds present in the fruit extracts.

\section{Conclusion}

The present study revealed the $\alpha$-glucosidase and antioxidant properties of three Brazilian native fruit (araçá, pitanga and butiá). Yellow and red araçás genotypes where the most promising extracts on the inhibition of $\alpha$-glucosidase with $\mathrm{IC}_{50}$ values much lower than the positive control acarbose. Nevertheless, purple, red and orange pitangas genotypes also showed potent inhibitory activity against the enzyme and all extracts were also potent antioxidants. These results may be partially explained by the presence and combination of phenolic compounds, anthocyanins, carotenoids and reducing sugars. Nonetheless, an extensive investigation is required to further characterize the compounds behind the $\alpha$-glucosidase inhibition and to understand the relation between the reducing sugars present in the fruits and their biological role. Overall, this study indicates that the native fruits extracts are excellent source of bioactive compounds that can be used to decrease blood glucose and also protect T2DM patients by improving their antioxidant status.

\section{Conflict of interest statement}

None declared. 


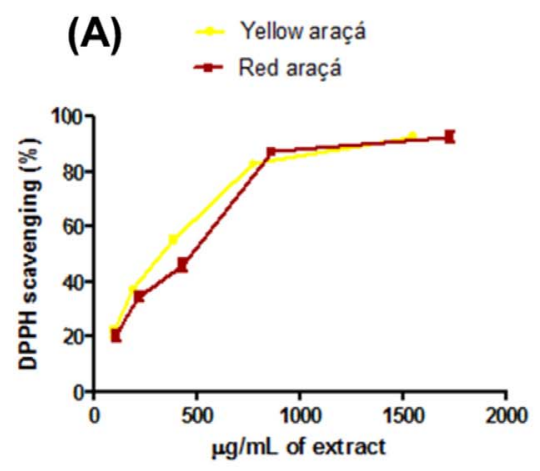

(B) $\quad$ Yellow araçá

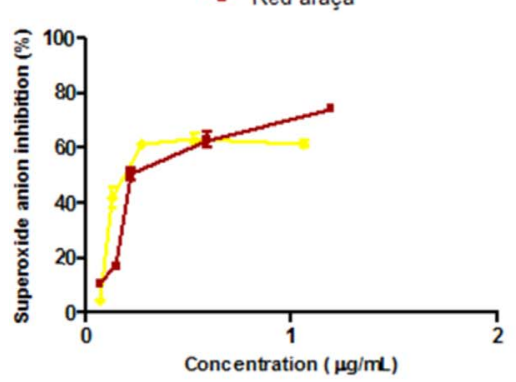

(C)

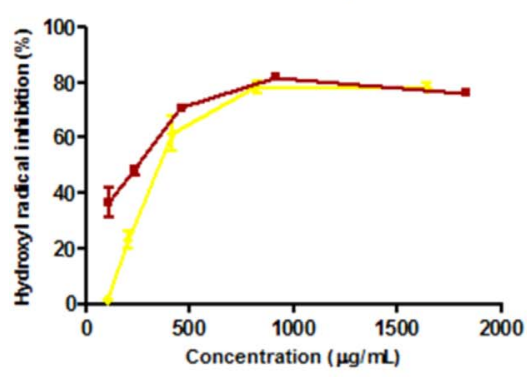

(D)

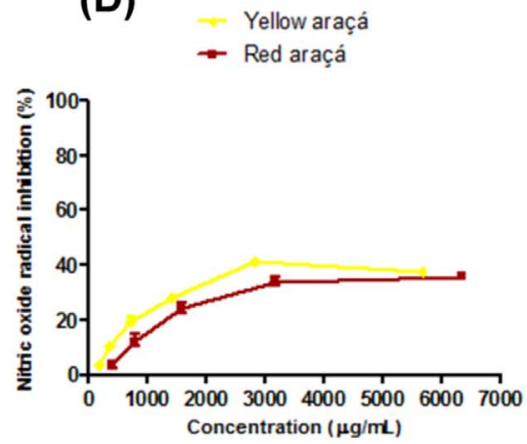

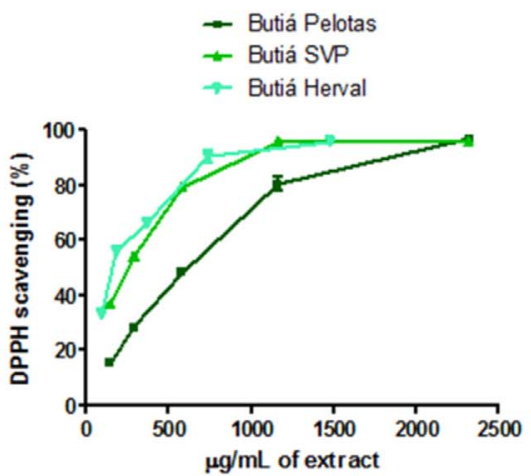

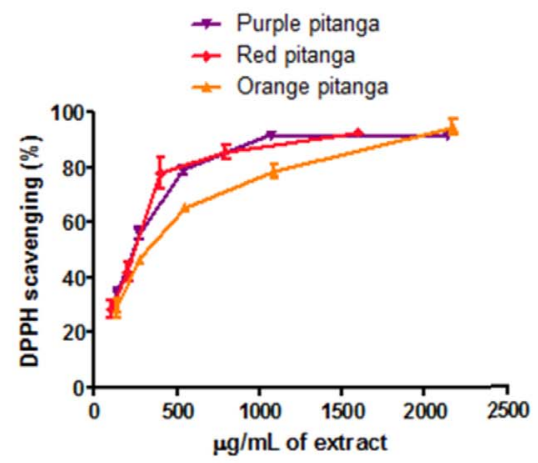

- Butiá Pelotas

- Butia SPV

- Butiá Herval

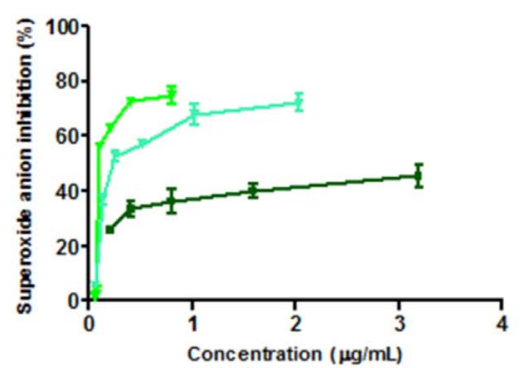

$\rightarrow$ Purple pitanga

$\leftarrow$ Red pitanga

- Orange pitanga



- Butiá Pelotas

- Butiá SVP

$\rightarrow$ Butiá Herval

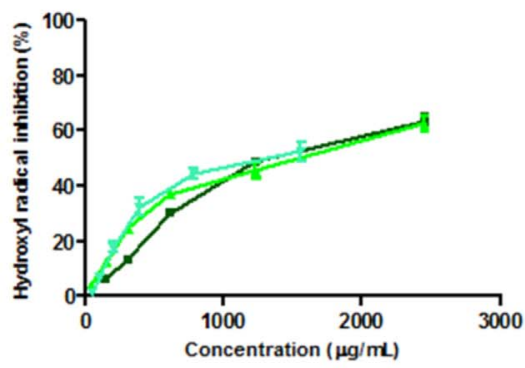

- Purple pitanga

- Red pitanga

- Orange pitanga

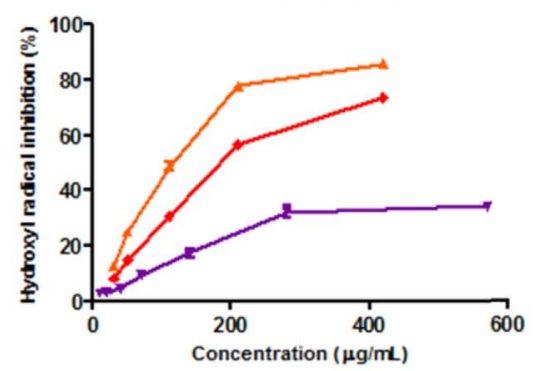

- Butiá Pelotas

* Butiá SVP

- Butiá Herval
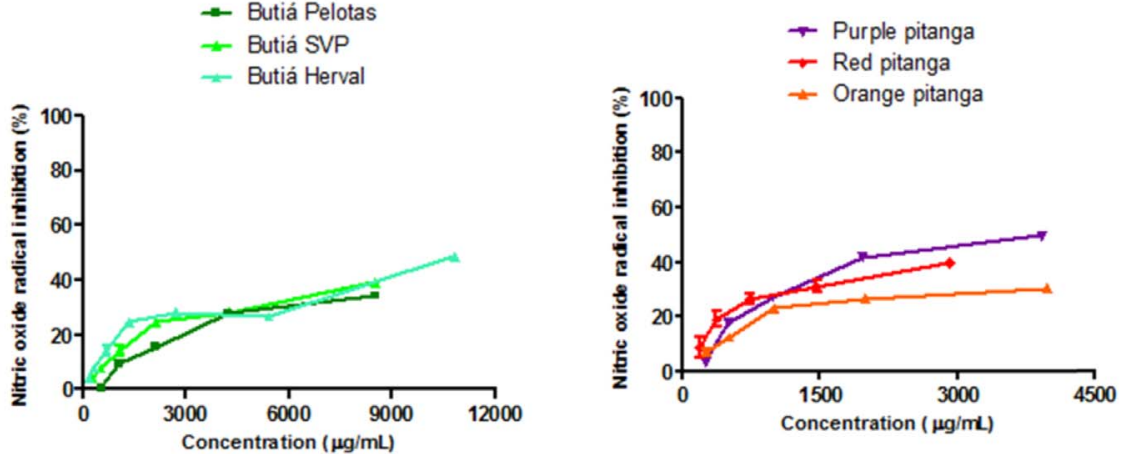

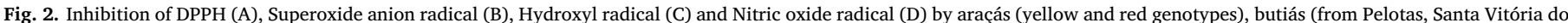


in triplicate. (For interpretation of the references to color in this figure legend, the reader is referred to the web version of this article).

\section{Acknowledgments}

This work was carried out with CNPq support, National Council for Scientific and Technological Development Brazil (process number 400201/2014-3). Authors are thankful to for the financial support of
CNPq/ Science Without Borders Program project "Frutas Nativas do Brasil: potencial anti-hiperglicimiante e antioxidante". J. Vinholes (process number 313712/2014-0) and G. Lemos thanks the Science Without Borders Program (CNPq) for the Young Talent Attraction and Scientific Initiation fellowships. 


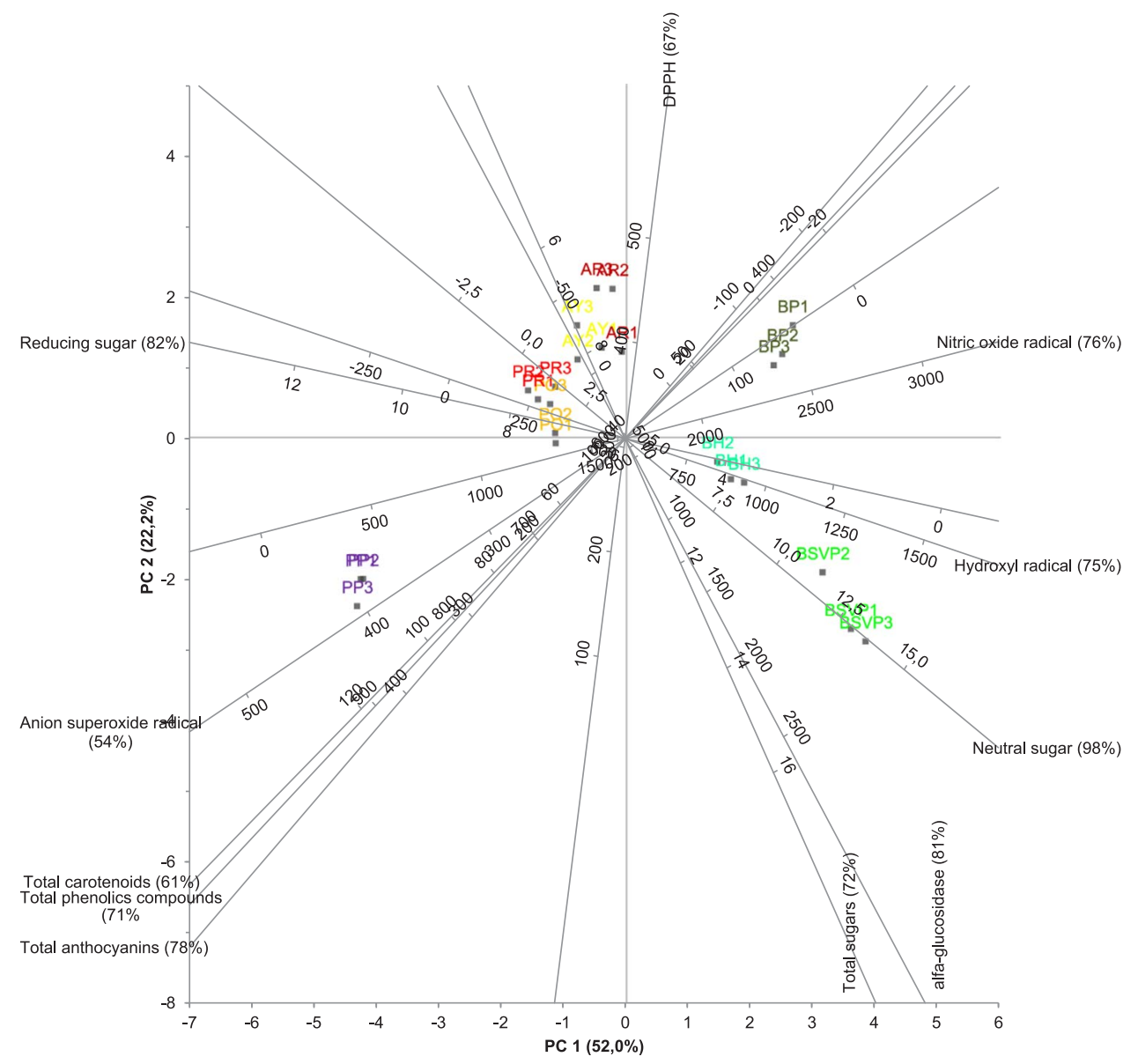

Fig. 3. Principal component analysis biplot of the contributions of variables (chemical composition and biological activity) to the principal components and samples scores of yellow araçá (AY), red araçá (AR), butiá from Pelotas (BP), butiá from Herval (BH), butiá from Santa Vitória do Palmar (BSVP), purple pitanga (PP), red pitanga (PR), orange pitanga (PO). (For interpretation of the references to color in this figure legend, the reader is referred to the web version of this article).

Table 3

Pearson's correlation matrix of the dataset. Pair-wise Pearson correlation coefficients $(r)$ were calculated from the chemical composition and observed activities for the native fruit ethanolic extracts samples. Blue indicates positive correlations and red negative correlations and the colour scale indicates de degree of correlation.

\begin{tabular}{|c|c|c|c|c|c|c|c|c|c|c|c|}
\hline Pearson's r & $\begin{array}{c}\alpha- \\
\text { glucosidase }\end{array}$ & DPPH & $\begin{array}{l}\text { Anion } \\
\text { superoxide } \\
\text { radical }\end{array}$ & $\begin{array}{l}\text { Hydroxyl } \\
\text { radical }\end{array}$ & $\begin{array}{l}\text { Nitric } \\
\text { oxide } \\
\text { radical }\end{array}$ & $\begin{array}{c}\text { Total } \\
\text { phenolics } \\
\text { compounds }\end{array}$ & $\begin{array}{c}\text { Total } \\
\text { anthocyanins }\end{array}$ & $\begin{array}{c}\text { Total } \\
\text { carotenoids }\end{array}$ & $\begin{array}{l}\text { Total } \\
\text { sugars }\end{array}$ & $\begin{array}{l}\text { Reducing } \\
\text { sugar }\end{array}$ & $\begin{array}{l}\text { Neutral } \\
\text { sugar }\end{array}$ \\
\hline a-glucosidase & - & $-0,412$ & $-0,283$ & 0,497 & 0,310 & $-0,170$ & $-0,209$ & $-0,250$ & 0,779 & $-0,556$ & 0,809 \\
\hline DPPH & $-0,412$ & - & $-0,325$ & $-0,061$ & 0,367 & $-0,263$ & $-0,350$ & $-0,517$ & $-0,294$ & $-0,064$ & $-0,126$ \\
\hline $\begin{array}{r}\text { Anion Superoxide } \\
\text { radical }\end{array}$ & $-0,283$ & $-0,325$ & - & $-0,318$ & $-0,548$ & 0,778 & 0,732 & 0,272 & $-0,394$ & 0,373 & $-0,499$ \\
\hline Hydroxyl radical & 0,497 & $-0,061$ & $-0,318$ & - & 0,818 & $-0,458$ & $-0,476$ & $-0,551$ & 0,379 & $-0,916$ & 0,815 \\
\hline Nitric oxide radical & 0,310 & 0,367 & $-0,548$ & 0,818 & - & $-0,560$ & $-0,514$ & $-0,566$ & 0,334 & $-0,849$ & 0,742 \\
\hline $\begin{array}{r}\text { Total phenolics } \\
\text { compounds }\end{array}$ & $-0,170$ & $-0,263$ & 0,778 & $-0,458$ & $-0,560$ & - & 0,903 & 0,470 & $-0,091$ & 0,496 & $-0,413$ \\
\hline Total anthocyanins & $-0,209$ & $-0,350$ & 0,732 & $-0,476$ & $-0,514$ & 0,903 & - & 0,644 & $-0,068$ & 0,488 & $-0,400$ \\
\hline Total carotenoids & $-0,250$ & $-0,517$ & 0,272 & $-0,551$ & $-0,566$ & 0,470 & 0,644 & - & 0,008 & 0,650 & $-0,442$ \\
\hline Total sugars & 0,779 & $-0,294$ & $-0,394$ & 0,379 & 0,334 & $-0,091$ & $-0,068$ & 0,008 & - & $-0,382$ & 0,779 \\
\hline Reducing sugar & $-0,556$ & $-0,064$ & 0,373 & $-0,916$ & $-0,849$ & 0,496 & 0,488 & 0,650 & $-0,382$ & - & $-0,857$ \\
\hline Neutral sugar & 0,809 & $-0,126$ & $-0,499$ & 0,815 & 0,742 & $-0,413$ & $-0,400$ & $-0,442$ & 0,779 & $-0,857$ & - \\
\hline
\end{tabular}

\section{Appendix A. Supporting information}

Supplementary data associated with this article can be found in the online version at http://dx.doi.org/10.1016/j.fbio.2017.06.005.

\section{References}

Alvarenga, F. Q., Mota, B. C. F., Leite, M. N., Fonseca, J. M. S., Oliveira, D. A., De Andrade Royo, V., et al. (2013). In vivo analgesic activity, toxicity and phytochemical screening of the hydroalcoholic extract from the leaves of Psidium cattleianum Sabine. Journal of Ethnopharmacology, 150(1), 280-284.

Bagetti, M., Facco, E. M. P., Piccolo, J., Hirsch, G. E., Rodriguez-Amaya, D., Kobori, C. N., et al. (2011). Physicochemical characterization and antioxidant capacity of pitanga fruits (Eugenia uniflora L.). Ciência E Tecnologia de Alimentos, 31(1), 147-154.

Balisteiro, D. M., Alezandro, M. R., \& Genovese, M. I. (2013). Characterization and effect of clarified araçá (Psidium guineenses Sw.) juice on postprandial glycemia in healthy subjects. Food Science and Technology, 33, 66-74.

Beskow, G. T., Hoffmann, J. F., Teixeira, A. M., Fachinello, J. C., Chaves, F. C., \& Rombaldi, C. V. (2014). Bioactive and yield potential of jelly palms (Butia odorata Barb. Rodr.). Food Chemistry, 172, 699-704.

Britton, G., \& Khachik, F. (2009). Carotenoids in food. Carotenoids volume 5: nutrition and health (45-66). 5(3).

Celli, G. B., Pereira-Netto, A. B., \& Beta, T. (2011). Comparative analysis of total phenolic content, antioxidant activity, and flavonoids profile of fruits from two varieties of Brazilian cherry (Eugenia uniflora L.) throughout the fruit developmental stages. Food Research International, 44(8), 2442-2451. 
Correia, R. T. P., Borges, K. C., Medeiros, M. F., \& Genovese, M. I. (2012). Bioactive compounds and phenolic-linked functionality of powdered tropical fruit residues. Food Science and Technology International = Ciencia Y Tecnología de Los Alimentos Internacional, 18(6), 539-547.

Cruxen, C. E. S., Hoffmann, J. F., Zandoná, G. P., Fiorentini, Â. M., Rombaldi, C. V., \& Chaves, F. C. (2017). Probiotic butiá (Butia odorata) ice cream: Development, char acterization, stability of bioactive compounds, and viability of Bifidobacterium lactis during storage. LWT - Food Science and Technology, 75, 379-385.

Denardin, C. C., Hirsch, G. E., da Rocha, R. F., Vizzotto, M., Henriques, A. T., Moreira, J. C. F., et al. (2014a). Antioxidant capacity and bioactive compounds of four Brazilian native fruits. Journal of Food and Drug Analysis, 1-12.

Denardin, C. C., Parisi, M. M., Martins, L. A. M., Terra, S. R., Borojevic, R., Vizzotto, M., et al. (2014b). Antiproliferative and cytotoxic effects of purple pitanga (Eugenia uniflora L.) extract on activated hepatic stellate cells. Cell Biochemistry and Function, 32(1), 16-23.

Devalaraja, S., Jain, S., \& Yadav, H. (2011). Exotic fruits as therapeutic complements for diabetes, obesity and metabolic syndrome. Food Research International, 44(7), $1856-1865$.

Do, Q. D., Angkawijaya, A. E., Tran-Nguyen, P. L., Huynh, L. H., Soetaredjo, F. E., Ismadji, S., \& Ju, Y. H. (2014). Effect of extraction solvent on total phenol content, total flavonoid content, and antioxidant activity of Limnophila aromatica. Journal of Food and Drug Analysis, 22(3), 296-302.

Ferrão, T. S., Ferreira, D. F., Flores, D. W., Bernardi, G., Link, D., Barin, J. S., \& Wagner, R. (2013). Evaluation of composition and quality parameters of jelly palm (Butia odorata) fruits from different regions of Southern Brazil. Food Research International, 54(1), 57-62.

Fetter, M. D. R., Vizzotto, M., Corbelini, D. D., \& Gonzalez, T. N. (2010). Propriedades funcionais de araçá-amarelo, araçá-vermelho (Psidium cattleyanum Sabine) e araçápera (P. acutangulum D.C.) cultivados em Pelotas/RS. Brazilian Journal of Food Technology, 13(EE01), 92-95.

Fuleki, T., \& Francis, F. J. (1968). Quantitative methods for anthocyanins. Journal of Food Science, 33(1), 72-77.

Giada, M. L. R. (2013). Food phenolic compounds: main classes, sources and their antioxidant power. In J. A. Morales-González (Ed.), Oxidative stress and chronic degenerative diseases - a role for antioxidants (pp. 87-112). Rijeka, Croatia: InTech.

Gonçalves, A. E. S. S., Lajolo, F. M., \& Genovese, M. I. (2010). Chemical composition and antioxidant/antidiabetic potential of Brazilian native fruits and commercial frozen pulps. Journal of Agricultural and Food Chemistry, 58(8), 4666-4674.

Hoffmann, J. F., Barbieri, R. L., Rombaldi, C. V., \& Chaves, F. C. (2014). Butia spp. (Arecaceae): An overview. Scientia Horticulturae, 179, 122-131.

Lee, S. Y., Abas, F., Khatib, A., Ismail, I. S., Shaari, K., \& Zawawi, N. (2016). Metabolite profiling of Neptunia oleracea and correlation with antioxidant and $\alpha$-glucosidase inhibitory activities using $1 \mathrm{H}$ NMR-based metabolomics. Phytochemistry Letters, 16, 23-33.

Li, D.-Q., Qian, Z.-M., \& Li, S.-P. (2010). Inhibition of three selected beverage extracts on $\alpha$-glucosidase and rapid identification of their active compounds using HPLC-DADMS/MS and biochemical detection. Journal of Agricultural and Food Chemistry, 58(11), 6608-6613.

Lima, V. L. A. G., Mélo, E. D. A., \& Lima, D. E. D. S. (2002). Fenólicos e carotenóides totais em pitanga. Scientia Agricola, 59, 447-450. http://dx.doi.org/10.1590/S010390162002000300006.

Lozano, V. V., Vélez, L. F. O., \& Rojano, B. A. (2013). Cambios en la actividad antioxidante durante el desarrollo de frutos de Psidium cattleianum Sabine (Myrtaceae)/ Changes in the antioxidant activity during the development in fruits of Psidium cattleianum Sabine (Myrtaceae). Revista Facultad Nacional de Agronomía, 66(1), 6939-6947.

Malinski, T. (2000). The vital role of nitric oxide. The Oakland University Journal, 47-57.

Matsui, T., Ueda, T., Oki, T., Sugita, K., Terahara, N., \& Matsumoto, K. (2001). a-glucosidase inhibitory action of natural acylated anthocyanins. 1. Survey of natural pigments with potent inhibitory activity. Journal of Agricultural and Food Chemistry, 49(4), 1948-1951.

Medina, A. L., Haas, L. I. R., Chaves, F. C., Salvador, M., Zambiazi, R. C., Da Silva, W. P., et al. (2011). Araçá (Psidium cattleianum Sabine) fruit extracts with antioxidant and antimicrobial activities and antiproliferative effect on human cancer cells. Food Chemistry, 128(4), 916-922.

Mitra, S. K., Irenaeus, T. K. S., Gurung, M. R., \& Pathak, P. K. (2012). Taxonomy and importance of Myrtaceae. Acta Horticulturae, 959, 23-34.

Muraki, I., Imamura, F., Manson, J. E., Hu, F. B., Willett, W. C., van Dam, R. M., \& Sun, Q.
(2013). Fruit consumption and risk of type 2 diabetes: Results from three prospective longitudinal cohort studies. British Medical Journal, 347(August), f5001.

Nelson, N. (1944). A photometric adaptation of Somogyi method for the determination of glucose. The Journal of Biological Chemistry, 3(2), 375-380.

Nora, C. D., Jablonski, A., Rios, A. O., Hertz, P. F., de Jong, E. V., \& Flôres, S. H. (2014) The characterisation and profile of the bioactive compounds in red guava (Psidium cattleyanum Sabine) and guabiju (Myrcianthes pungens (O. Berg) D. Legrand). International Journal of Food Science \& Technology, 49(8), 1842-1849.

Pereira, M. C., Steffens, R. S., Jablonski, A., Hertz, P. F., De O. Rios, A., Vizzotto, M., \& Flôres, S. H. (2012). Characterization and antioxidant potential of Brazilian fruits from the Myrtaceae family. Journal of Agricultural and Food Chemistry, 60(12), 3061-3067.

Polidori, M. C., Mecocci, P., Stahl, W., Parente, B., Cecchetti, R., Cherubini, A., et al. (2000). Plasma levels of lipophilic antioxidants in very old patients with type 2 diabetes. Diabetes/Metabolism Research and Reviews, 16(1), 15-19.

Polidori, M. C., Stahl, W., Eichler, O., Niestroj, I., \& Sies, H. (2001). Profiles of antioxidants in human plasma. Free Radical Biology \& Medicine, 30(5), 456-462.

Rao, A., \& Rao, L. (2007). Carotenoids and human health. Pharmacological Research, 55(3), 207-216.

Ribeiro, A. B., Chisté, R. C., Freitas, M., Da Silva, A. F., Visentainer, J. V., \& Fernandes, E. (2014). Psidium cattleianum fruit extracts are efficient in vitro scavengers of physiologically relevant reactive oxygen and nitrogen species. Food Chemistry, 165, $140-148$.

Sajak, A. A. B., Abas, F., Ismail, A., \& Khatib, A. (2016). Effect of different drying treatments and solvent ratios on phytochemical constituents of Ipomoea aquatica and correlation with $\alpha$-glucosidase inhibitory activity. International Journal of Food Properties, 19(12), 2817-2831.

SBD (2013). São 13.4 milhões de pessoas portadoras de diabetes no Brasil. Retrieved August 10, 2013, from 〈http://www.diabetes.org.br/sala-de-noticias/2364-sao-134milhoes-de-pessoas-portadoras-de-diabetes-no-brasilbetes-no-Brasil $>$.

Soares, D. J., Walker, J., Pignitter, M., Walker, J. M., Imboeck, J. M., Ehrnhoefer-Ressler, M. M., et al. (2014). Pitanga (Eugenia uniflora L.) fruit juice and two major constituents thereof exhibit anti-inflammatory properties in human gingival and oral gum epithelial cells. Food \& Function, 5(11), 2981-2988.

Swain, T., \& Hillis, W. E. (1959). The phenolic constituents of Prunus domestica. I.-The quantitative analysis of phenolic constituents. Journal of the Science of Food and Agriculture, 10(1), 63-68.

Talcott, S. T., \& Howard, L. R. (1999). Phenolic autoxidation is responsible for color degradation in processed carrot puree. Journal of Agricultural and Food Chemistry, 47(5), 2109-2115.

Trevithick-Sutton, C. C., Foote, C. S., Collins, M., \& Trevithick, J. R. (2006). The retinal carotenoids zeaxanthin and lutein scavenge superoxide and hydroxyl radicals: A chemiluminescence and ESR study. Molecular Vision, 12(September), 1127-1135.

Valabhji, J., McColl, A. J., Richmond, W., Schachter, M., Rubens, M. B., \& Elkeles, R. S. (2001). Total antioxidant status and coronary artery calcification in Type 1 diabetes. Diabetes Care, 24(9), 1608-1613.

Vinholes, J., Gelain, D. P., \& Vizzotto, M. (2016). Stone fruits as a source of bioactive compounds. In L. R. da Silva, \& B. M. Silva (Vol. Eds.), Natural bioactive compounds from fruits and vegetables as health promoters part I. 1, (pp. 110-142). Sharjah: Bentham Science Publishers.

Vinholes, J., Gonçalves, P., Martel, F., Coimbra, M. A., \& Rocha, S. M. (2014). Assessment of the antioxidant and antiproliferative effects of sesquiterpenic compounds in in vitro Caco-2 cell models. Food Chemistry, 156, 204-211.

Vinholes, J., Grosso, C., Andrade, P. B., Gil-Izquierdo, A., Valentão, P., Pinho, P. G. D., \& Ferreres, F. (2011). In vitro studies to assess the antidiabetic, anti-cholinesterase and antioxidant potential of Spergularia rubra. Food Chemistry, 129(2), 454-462.

Vissotto, L. C., Rodrigues, E., Chisté, R. C., Benassi, M. D. T., \& Mercadante, A. Z. (2013). Correlation, by multivariate statistical analysis, between the scavenging capacity against reactive oxygen species and the bioactive compounds from frozen fruit pulps. Ciência E Tecnologia de Alimentos, 33, 57-65.

Xu, J., Hagler, A., Xu, J., \& Hagler, A. (2002). Chemoinformatics and drug discovery. Molecules, 7(8), 566-600.

Yan, C., Lee, J., Kong, F., \& Zhang, D. (2013). Anti-glycated activity prediction of polysaccharides from two guava fruits using artificial neural networks. Carbohydrate Polymers, 98(1), 116-121.

Zou, Y., Lu, Y., \& Wei, D. (2004). Antioxidant activity of a flavonoid-rich extract of Hypericum perforatum L. in vitro. Journal of Agricultural and Food Chemistry, 52(16), 5032-5039. 